\title{
HIGH SENSITIVITY C-REACTIVE PROTEIN SEBAGAI FAKTOR RESIKO INDEPENDEN DIBANDING FAKTOR RESIKO KARDIOVASKULER KLASIK PADA INFARK MIOKARD AKUT
}

\author{
Eka Fithra Elfi
}

\begin{abstract}
Abstrak
Penelitian ini bertujuan menganalisis hubungan antara hs-CRP dengan faktor resiko kardiovaskuler klasik pada pasien dengan infark miokard akut. Penelitian ini merupakan subgroup analisis pada penderita infark miokard akut yang dirawat di RSUP Dr.M.Djamil mulai Januari-April 2013. Faktor resiko kardiovaskuler sebagai variabel independen berupa umur, riwayat hipertensi, diabetes, merokok, dan dislipidemia. Pengukuran IMT, profil lipid, dan gula darah random diambil saat pasien masuk dan diperiksa di Laboratorium Sentral RSUP Dr. M. Djamil Padang. Variabel dependen hs-CRP diambil dalam 24-36 jam rawatan dan diperiksa dengan metode ELISA. Data dianalisis dengan t-test dan uji korelasi Pearson. Hasil penelitian menunjukkan peningkatan hs-CRP, secara statistik berhubungan signifikan terhadap IMT $(r=0,45 ; p=0,01)$, namun tidak berhubungan dengan faktor resiko kardiovaskuler lain seperti usia, hipertensi, diabetes, merokok, dan dislipidemia. Penelitian ini dapat disimpulkan bahwa peningkatan hs-CRP tidak berhubungan dengan faktor resiko kardiovaskuler klasik dan hs-CRP merupakan faktor resiko yang bersifat independen. Pemeriksaan ini bisa menjadi prediksi penyakit kardiovaskuler dan juga sebagai nilai prognostik pada pasien infark miokard akut.

Kata Kunci : hs-CRP, infark miokard akut, inflamasi, faktor resiko kardiovaskuler
\end{abstract}

\begin{abstract}
This study aimed to analyze the relationship between hs-CRP with classic cardiovascular risk factors in patients with acute myocardial infarction. This study was a subgroup analysis in patients with acute myocardial infarction who were hospitalized in Dr.M.Djamil hospital started from January to April 2013. Cardiovascular risk factors as independent variables were age, history of hypertension, diabetes, smoking, and dyslipidemia. Measurement of BMI, lipid profile, and random blood sugar were taken and examined at admission. The dependent variable hsCRP were taken within 24-36 hours of admission and examined by ELISA. Data was analyzed by t-test and Pearson correlation test. The results showed an increase in hs-CRP and significantly related to $B M I(r=0.45 ; p=0.01)$, but not associated with other cardiovascular risk factors such as age, hypertension, diabetes, smoking, and dyslipidemia. It was concluded that increased hsCRP was not associated with classic cardiovascular risk factors and hs-CRP is an independent risk factor. Hs-CRP examination could be a predictive of cardiovascular disease as well as prognostic value in patients with acute myocardial infarction.
\end{abstract}

Keywords: hs-CRP, acute myocardial infarction, inflammatory, cardiovascular risk factors

Afiliasi Penulis: Bagian Kardiologi dan Vaskular Fakultas Kedokteran Universitas Andalas/RSUP Dr.M.Djamil Padang, Korespondensi: Eka Fithra Elfi, Jl. Peritnis Kemerdekaan No. 94, PO BOX 49 Padang 25127, Email: ekafithra@yahoo.com. 


\section{PENDAHULUAN}

Inflamasi pada penyakit jantung koroner (PJK) dan infark miokard akut (IMA) merupakan keadaan akibat terbentuknya plak ateroma pada arteri koroner. Mekanisme kompleks terbentuknya plak ateroma ditengarai oleh inflamasi mulai dari disfungsi endotel hingga timbulnya instabilitas dan ruptur plak ateroma serta peningkatan aktivitas kaskade koagulasi. ${ }^{1,2}$ Salah satu parameter yang mudah diukur untuk menilai derajat inflamasi pada infark miokard akut adalah dengan pengukuran $C$ reactive protein (CRP).

CRP merupakan protein fase akut yang dirilis setelah timbul suatu stimulus inflamasi. Pada aterosklerosis CRP berperan penting untuk mediator kejadian aterotrombosis dan ruptur plak melalui aktivasi komplemen, memicu dan meningkatkan disfungsi serta destruksi sel endotel, memicu ekspresi molekul adhesi, merangsang produksi faktor jaringan oleh makrofag, menghambat produksi nitricoxide (NO), menghambat angiogenesis, serta meningkatkan penebalan tunika intima dan menghambat degradasi fibrous cap., ${ }^{3,4}$ Peningkatan CRP juga ditemukan pada angina tidak stabil dan IMA, serta dianggap menunjukkan prognosis jangka pendek yang buruk, terlepas dari beratnya iskemia dan derajat aterosklerosis. ${ }^{5}$ Pemeriksaan high sensitivity-CRP (hsCRP) yang lebih sensitif dilaporkan memberi nilai tambah prognostik terhadap skor resiko kardiovaskular klasik dari Framingham, bahkan dianggap sebagai prediktor yang lebih kuat dibanding kolesterol low-density lipoprotein (LDL-C). ${ }^{6}$
Framingham Heart Study merupakan penelitian epidemiologi yang meneliti hubungan antara faktor resiko tradisional terhadap kejadian kardiovaskuler pada populasi di Amerika. Faktor resiko yang dianalisa meliputi umur, kolesterol total, kolesterol high density lipoprotein (HDL), indeks massa tubuh (IMT), tekanan darah sistolik, merokok, dan diabetes. Data faktor resiko tersebut diidentifikasi dan diaplikasikan secara global sebagai Framingham Risk Score yang memprediksi kejadian kardiovaskuler dalam 10 tahun berupa angina, penyakit jantung koroner, IMA, dan kematian akibat kardiovaskuler. Skor resiko Framingham ini digunakan secara luas di dunia sebagai model prediktif, walaupun dianggap memiliki beberapa kelemahan seperti kurang terwakilinya serta overestimasi resiko pada populasi Asia. ${ }^{7}$

Model prediksi lain yang dibuat beberapa negara umumnya hampir serupa dengan skor Framingham dengan beberapa modifikasi. Skor yang cukup dikenal antara lain QRISK di Inggris, EURO SCORE di Eropa, atau Jakarta Score di Indonesia. Namun demikian skor Framingham secara global masih dianggap sebagai skor prediktif yang akurat dan bermanfaat dalam mengidentifikasi faktor resiko kardiovaskuler dan merancang program prevensi primer. 8

CRP sebagai faktor resiko kardiovaskuler tambahan telah dituangkan kedalam skor resiko Reynolds, yang ditujukan untuk menilai faktor resiko baru seperti CRP dan HbA1C terhadap populasi pria dan wanita. Hs-CRP dianggap memberikan manfaat lebih tinggi dalam menentukan resiko kejadian kardiovaskuler, khususnya untuk popu- 
lasi pasien diatas 50 tahun. ${ }^{9,10}$ Selain itu penelitian besar JUPITER menunjukkan peningkatan resiko kejadian kardiovaskuler yang independen terhadap kadar kolesterol LDL dan HDL pada grup pasien dengan resiko sedang. Hs-CRP lebih dari $3 \mathrm{mg} / \mathrm{L}$ dianggap meningkatkan resiko kardiovaskuler yang signifikan. ${ }^{11}$ Khusus untuk populasi di Sumatera Barat belum ada penelitian yang menguji apakah Hs-CRP berhubungan dengan faktor resiko kardiovaskuler klasik Framingham.

Penelitian ini menganalisa hubungan antara kadar Hs-CRP pada pasien dengan infark miokard akut terhadap faktor resiko kardiovaskular klasik Framingham.

\section{METODE}

Penelitian ini merupakan uji analitik terhadap hubungan kadar HsCRP dengan faktor resiko kardiovaskular klasik Framingham. Penelitian dilakukan di Instalasi Pusat Jantung RSUP Dr. M. Djamil Padang periode Januari hingga April 2013. Subjek penelitian adalah pasien dewasa berusia 30-75 tahun yang dirawat di Instalasi Pusat Jantung dan didiagnosis sebagai infark miokard akut (IMA) dengan ST-segmen elevasi (STEMI) serta non ST-segmen elevasi (NSTEMI) yang dipilih secara konsekutif. Faktor resiko kardiovaskular klasik yang dianalisa sebagai variabel independen meliputi umur, jenis kelamin, indeks massa tubuh, profil lipid, hipertensi, diabetes, dan status merokok yang diukur langsung maupun dengan menggunakan kuisioner sebagai riwayat faktor resiko. Data laboratorium seperti leukosit, gula darah random, dan fungsi ginjal juga diperiksa untuk menghindari bias pengaruh metabolik terhadap kadar hs-CRP. Pemeriksaan hs-CRP diambil dalam 24 jam pertama rawatan sebagai variabel dependen dan dianalisa di Laboratorium Biomedik Fakultas Kedokteran Universitas Andalas dengan metode immunoassay ELISA menggunakan reagen anti-CRP Accubind dari Monobind Inc. sesuai standar prosedur yang berlaku.

Untuk mengurangi bias perubahan kadar hs-CRP karena faktor lain, maka pasien dengan onset lebih dari 24 jam, riwayat henti jantung atau resusitasi jantung, pasien dengan kanker, inflamasi kronik, infeksi berat, sepsis, atau leukositosis berat dieksklusi dari penelitian ini. Inform consent untuk tindakan pengambilan darah dan data pasien diambil sebelum pasien diikutkan dalam penelitian ini. Data diolah menggunakan komputer dan dianalisis secara statistik dengan uji korelasi Pearson untuk data numerik serta uji $t$ test untuk data kategorik.

\section{HASIL DAN PEMBAHASAN}

Penelitian ini mengikutsertakan 33 subjek dengan IMA STEMI dan NSTEMI yang memenuhi kriteria inklusi dan eksklusi sepanjang Januari-April 2013. Karakteristik dasar, karakteristik klinik, dan data penunjang subjek penelitian ditampilkan pada tabel 1. Hampir seluruh pasien adalah pria dengan rerata umur 57,9 tahun, dengan IMT rerata 23,9 $\mathrm{kg} / \mathrm{m} 2$. Pada pasien tidak ditemukan luaran kardiovaskuler mayor seperti kematian, gagal jantung akut, serta stroke iskemik atau tromboembolik selama perawatan di rumah sakit. 
Tabel 1. Karakteristik Dasar Penderita Infark Miokard Akut

\begin{tabular}{|c|c|c|}
\hline Karakteristik $^{*}$ & Frekuensi (\%) & Rerata \\
\hline \multicolumn{3}{|l|}{ Demografi } \\
\hline Umur (Tahun) & & $57,9(6,6)$ \\
\hline Pria & $32(97)$ & \\
\hline Diagnosis STEMI & $22(66,7)$ & \\
\hline \multicolumn{3}{|l|}{ Faktor Resiko } \\
\hline IMT $\left(\mathrm{kg} / \mathrm{m}^{2}\right)$ & & $23,9(2,8)$ \\
\hline Hipertensi & $13(39,4)$ & \\
\hline Perokok Aktif & $15(45,5)$ & \\
\hline Diabetes Mellitus & $7(21,2)$ & \\
\hline Riwayat Dislipidemia & $3(9,1)$ & \\
\hline \multicolumn{3}{|l|}{ Laboratorium } \\
\hline Kolesterol Total (mg/dl) & & $192,4(36,2)$ \\
\hline Kolesterol LDL (mg/dl) & & $128,2(26,4)$ \\
\hline Kolesterol HDL (mg/dl) & & $40,6(8,4)$ \\
\hline Trigliserida (mg/dl) & & $124,8(70,3)$ \\
\hline Ureum (mg/dl) & & $27,8(13,5)$ \\
\hline Creatinin (mg/dl) & & $1,2(0,4)$ \\
\hline GDR (mg/dl) & & $169,5(75,7)$ \\
\hline Leukosit $\left(/ \mathrm{mm}^{3}\right)$ & & $9838(3980)$ \\
\hline \multicolumn{3}{|l|}{ Angiografi koroner } \\
\hline 1-Vessel & $11(33,3)$ & \\
\hline 2-Vessel & $8(24,2)$ & \\
\hline 3-Vessel & $6(18,2)$ & \\
\hline Left Main Lesion & $0(0)$ & \\
\hline
\end{tabular}

Keterangan: * 8 pasien tidak memiliki data angiografi koroner, IMT, Indeks Massa Tubuh; LDL, low density-lipoprotein; HDL, high density-lipoprotein; GDR, gula darah random.

Tabel 2 menunjukkan korelasi antara kadar hs-CRP pasien IMA dengan kadar kolesterol, ureum, kreatinin, dan gula darah sewaktu. Namun tidak ditemukan korelasi yang bermakna antara kadar hs-CRP dengan profil laboratorium yang diambil saat pasien masuk rawatan. Beratnya lesi koroner juga tidak berhubungan dengan kadar hs-CRP serum. Hubungan antara profil faktor resiko ditampilkan pada tabel 3. 
Tabel 2. Korelasi Hs-CRP dengan Profil Faktor Resiko Pasien

\begin{tabular}{lccc}
\hline \multicolumn{1}{c}{ Parameter } & $\begin{array}{c}\text { Rerata } \\
\text { hs-CRP(SD) }\end{array}$ & Nilai $\mathbf{r}(\mathbf{p})$ & Nilai $\mathbf{p}$ \\
\hline Umur & $57,9(6,6)$ & $-0,034$ & $\mathrm{p}=0,85$ \\
IMT & $23,9(2,8)$ & 0,405 & $\mathrm{p}=0,01$ \\
Kolesterol HDL & $128,2(26,4)$ & $-0,141$ & $\mathrm{p}=0,43$ \\
Kolesterol LDL & $40,6(8,4)$ & $-0,199$ & $\mathrm{p}=0,27$ \\
Kolesterol total & $192,4(36,2)$ & $-0,269$ & $\mathrm{p}=0,13$ \\
Trigliserida & $124,8(70,3)$ & 0,041 & $\mathrm{p}=0,81$ \\
Ureum & $27,8(13,5)$ & $-0,086$ & $\mathrm{p}=0,63$ \\
Creatinin & $1,2(0,4)$ & 0,128 & $\mathrm{p}=0,48$ \\
GDR & $169,5(75,7)$ & 0,064 & $\mathrm{p}=0,72$ \\
Leukosit & $9838(3980)$ & 0,330 & $\mathrm{p}=0,06$ \\
\hline
\end{tabular}

Table 3. Hubungan Faktor Resiko Kardiovaskuler dengan Nilai Hs-CRP

\begin{tabular}{lcc}
\hline \multicolumn{1}{c}{ Parameter } & Hs-CRP, rerata (SD) & Nilai $\mathbf{p}$ \\
\hline Riwayat Hipertensi & & \\
Hipertensi $(\mathrm{n}=20)$ & $41,33(17,24)$ & 0,59 \\
Tidak Hipertensi $(\mathrm{n}=13)$ & $37,25(22,61)$ & \\
Riwayat Diabetes & $39,33(21,03)$ & \\
Diabetes $(\mathrm{n}=26)$ & $41,18(11,85)$ & \\
Tidak diabetes $(\mathrm{n}=7)$ & & \\
Riwayat Dislipidemia & $40,50(19,23)$ & \\
Dislipidemia $(\mathrm{n}=3)$ & $31,90(22,24)$ & \\
Tidak dislipidemia $(\mathrm{n}=30)$ & & \\
Kebiasaan Merokok & & \\
Perokok $(\mathrm{n}=18)$ & $31,43(16,81)$ & \\
Tidak perokok $(\mathrm{n}=15)$ & $37,67(22,35)$ & \\
\hline
\end{tabular}

Tabel 3. menunjukkan dimana hanya ditemukan korelasi lemah antara kadar hs-CRP dengan IMT pasien IMA $(r=0,4 ; \quad p=0,03)$. Uji t-test juga menunjukkan tidak terdapat hubungan yang signifikan antara kadar hs-CRP dengan faktor resiko diabetes, riwayat dislipidemia, hipertensi, dan merokok. Uniknya walaupun penanda inflamasi, namun tidak terlihat hubungan dengan kadar leukosit pasien dengan IMA. 
CRP merupakan protein fase akut yang dirilis saat terjadi proses inflamasi, namun juga berperan dalam meningkatkan sitokin proinflamasi interleukin10, menghambat ekspresi nitric-oxide synthase, dan meningkatkan ekspresi molekul adhesi sel endotel, sehingga peningkatan CRP dianggap berperan penting terhadap penyakit kardiovaskuler. Pasien dengan kadar hs-CRP yang tinggi beresiko hingga dua kali lipat mengalami infark miokard akut. Selain itu pada kejadian infark miokard akut, kadar hs-CRP menunjukkan nilai prognostik karena perannya sebagai mediator proinflamasi.

Aktivitas proinflamasi dan protrombotik CRP menimbulkan suatu lingkaran setan pada infark miokard akut. Pada penelitian ini terlihat peningkatan hs-CRP yang signifikan pada kejadian infark miokard akut STEMI maupun NSTEMI. Penelitian sebelumnya menunjukkan bahwa peningkatan hs-CRP lebih signifikan pada pasien STEMI karena beratnya derajat nekrosis dan inflamasi, namun pada penelitian ini tidak terdapat perbedaan bermakna. ${ }^{12,13,14}$

Analisis terhadap hubungan faktor resiko kardiovaskuler klasik dengan kadar hs-CRP tidak ditemukan hubungan yang bermakna selain IMT. Penelitian JUPITER menunjukkan bahwa resiko penyakit kardiovaskuler lebih tinggi pada pasien dengan kadar kolesterol LDL tinggi dan kadar hs-CRP tinggi, namun resiko lebih tinggi pada pasien dengan hs-CRP yang tinggi walaupun kadar kolesterolnya normal. ${ }^{11}$

Pada penelitian ini tidak ditemukan hubungan antara profil lipid (kolesterol total, LDL, HDL, dan trigliserida) maupun terhadap riwayat faktor resiko kardiovaskuler lainnnya (dislipidemia, hipertensi, merokok, dan diabetes mellitus). Sementara data prospektif menunjukkan kadar hs-CRP berhubungan erat dengan faktor resiko seperti merokok, hipertensi, dan kadar kolesterol serta gula darah.

Rekomendasi dari Kanada menganjurkan pemeriksaan hs-CRP pada pasien dengan resiko menengah untuk panduan dalam memulai terapi, khususnya pada pasien dengan hs-CRP lebih dari $2 \mathrm{mg} / \mathrm{L} .{ }^{15}$ Penelitian Seok et al pada populasi Korea menunjukkan hubungan yang signifikan antara kadar CRP dengan setiap faktor resiko kardiovaskular dalam skor resiko Framingham. ${ }^{10}$ Penelitian Wilson et al menunjukkan bahwa CRP merupakan prediktor yang kuat namun tidak memberikan nilai tambah terhadap faktor resiko klasik lainnya. Data tersebut bersama data ini menunjukkan bahwa perubahan hs-CRP yang melibatkan inflamasi endotel merupakan faktor yang independen terhadap kejadian kardiovaskuler seperti IMA dan stroke. ${ }^{16}$ Namun demikian perlu diingat bahwa penelitian tersebut mengevaluasi populasi beresiko tinggi yang belum mengalami kejadian kardiovaskuler, sementara pada penelitian ini populasi yang dianalisa adalah pasien dengan infark miokard akut.

Pada penelitian Wong ditemukan peningkatan CRP pada pasien infark miokard dan diabetes yang independen terhadap faktor resiko seperti umur, jenis kelamin, dan status dislipidemia. ${ }^{17}$ Dengan demikian kemungkinan terdapat proses inflamasi yang lebih berat dan tidak dipengaruhi oleh faktor resiko 
dasar pasien tersebut, khususnya terhadap peran disfungsi endotel dan inflamasi pada infark miokard akut.

Hubungan yang bermakna ditemukan hanya antara IMT dengan kadar hs-CRP. Obesitas yang ditandai dengan IMT diatas 25 dihubungkan dengan peningkatan sitokin proinflamasi akibat penumpukan lemak viseral dan perubahan kadar adipokin (IL-6, TNF- $\alpha$ ). Kondisi ini menimbulkan status proinflamasi yang konstan setiap saat, termasuk pada saat terjadi infark miokard akut. Hal ini lebih bermakna pada pada obesitas sentral. Namun demikian, korelasi ini tidak dihubungkan dengan kadar kolesterol, status dislipidemia, maupun tanda-tanda sindroma metabolik, seperti yang ditunjukkan penelitian ini. $^{18,19,20}$

Penelitian ini merupakan analisis subgroup dari penelitian yang membandingkan peran statin terhadap respon inflamasi pada IMA, sehingga desain penelitian mungkin tidak sesuai dengan penghitungan jumlah sampel. Sehingga jumlah sampel pada penelitian ini cenderung lebih kecil. Namun demikian sampel pada grup ini dapat mewakili populasi yang sebenarnya dari pasien IMA di RSUP Dr. M. Djamil. Sampel lebih besar diperlukan untuk menilai lebih baik terhadap hubungan antara hsCRP dengan faktor resiko kardiovaskuler. Selain itu dibutuhkan penelitian lebih lanjut terhadap faktor yang memicu pelepasan CRP pada IMA, khususnya peran disfungsi endotel, karena disfungsi endotel merupakan pemicu awal terjadinya penyakit kardiovaskuler yang menimbulkan IMA.

\section{SIMPULAN}

Berdasarkan analisa korelasi, ditemukan hanya indeks massa tubuh yang berkorelasi lemah dengan kadar hs-CRP pada pasien dengan IMA, sementara tidak ditemukan hubungan dengan faktor resiko kardiovaskuler klasik lainnya. Hal ini menunjukkan bahwa hs-CRP merupakan parameter yang independen dibanding faktor resiko kardiovaskular klasik terhadap kejadian infark miokard akut. Data ini menunjukkan bahwa respon inflamasi pada pasien infark miokard akut tidak dipengaruhi oleh status dasar pasien seperti umur, jenis kelamin, hipertensi, diabetes, dan dyslipidemia. Sehingga pemeriksaan rutin hs-CRP dapat meningkatkan prediksi lebih baik pada pasien dengan resiko kardiovaskuler rendah atau moderat, begitu juga untuk meningkatkan nilai prognostik pada IMA. Mengingat CRP merupakan produk terhadap respon inflamasi, diperlukan penelitian lebih lanjut terhadap faktorfaktor yang menjadi pemicu inflamasi pada infark miokard, terutama biomarker terhadap disfungsi endotel. 


\section{DAFTAR RUJUKAN}

1. Packard RRS, Libby P. Inflammation in atherosclerosis: from vascular biology to biomarker discovery and risk prediction. Clin Chem 2008;54:24-38.

2. Hansson GK. Inflammation, atherosclerosis, and coronary artery disease. NEJM 2005;352:1685-95.

3. Collaboration TERF. C-reactive protein, fibrinogen, and cardio-vascular disease prediction. NEJM 2012;367:1310-20.

4. Ridker PM, Rifai N, Rose L, Buring JE, Cook NR. Comparison of c-reactive protein and low-density liporotein cholesterol levels in the prediction of first cardiovascular event. NEJM 2002;347:1557-65.

5. Shishehbor MH, Bhatt DL, Topol EJ. Using c-reactive protein to assess cardiovascular disease risk. Cleveland Clin J Med 2003;70: 634-40.

6. Devaraj S, Singh U, Jialal I. The evolving role of c-reactive protein in atherothrombosis. Clin Chem 2009;55:229-38.

7. O'Donnel CJ, Elosua R. Cardio vascular risk factors. Insights from Framingham heart study. Rev Esp Cardiol 2008;61(3):299-310.

8. D'Agostino RB, Vasan RS, Pencina MJ, Wolf PA, Cobain M, Massaro JM, et al. General cardiovascular risk profile for use in primary care. The Framingham heart study. Circulation 2008;117:74353.

9. Wilson PWF, Nam BH, Pencina $M$, D'Agostino RB, Benjamin EJ, O'Donnel CJ. C-reactive protein and risk of cardiovascular disease in men and women from the framigham heart study. Arch Intern Med 2005;165(21):2743-8.

10. Seok JH, Kim U, Lee SH, Hong GR, Park JS, Shin DG, et al. Correlation of c-reactive protein levels and Framingham coronary risk score. The Korean J Med 2007;73(3):283-92.

11. Ridker PM, Danielson E, Fonseca FAH, Genest J, Gotto Jr AM, Kastelein JJP, et al. Rosuvastatin to prevent vascular events in men and women with elevated c-reactive protein. NEJM 2008;359:2195-207.
12. Zamani $P$, Schwartz GG, Olsson AG, Rifai N, Bao W, Libby $P$, et al. Inflammatory biomarkers, death, and recurrent nonfatal coronary events after an acute coronary syndrome in the miracl study. J Am Heart Assoc 2013;2:e003103.

13. Habib SS, Kurdi MI, Aseri ZA, Suriya MO. CRP levels are higher in patients with ST elevation than non-ST elevation acute coronary syndrome. Arq Bras Cardiol 2011; 91:13-7.

14. Stefano RD, Bello VD, Barsotti MC, Grigoratos C, Armani C, Dell'Omodarme $\mathrm{M}$, et al. Inflammatory markers and cardiac function in acute coronary syndrome: Difference in ST-segment elevation myocardial infarction (stemi) and in non-stemi models. Biomed Pharmacother 2009;63:773-80.

15. Bosomworth NJ. Practical use of the Framingham risk score in primary prevention, Canadian perspective. Canadian Family Physician 2011; 57:417-23.

16. Wilson PWF, Pencina $M$, Jaques $P$, Selhub J, D'Agostino R, O'Donnel CJ. $\mathrm{C}$-reactive protein and reclassification of cardiovascular risk in the Framingham heart study. Circ Cardiovasc Qual Outcomes 2008;1(2):92-7.

17. Wong V, McLean M, Boyages SC, Cheung NW. C-reactive protein levels following acute myocardial infarction. Diabetes Care 2004;27 (2):2971-73.

18. Aronson D, Bartha $P$, Zinder $O$, Kerner A, Markiewicz W, Avizohar $O$, et al. Obesity is the major determinant of elevated c-reactive protein in subjects with the metabolic syndrome. Int $\mathrm{J}$ Obes Relat Metab Disord 2004;28(5):674-9.

19. Choi J, Joseph L, Pilote L. Obesity and c-reactive protein in various populations: a systematic review and meta-analysis. Obes Rev 2013; 14(3):232-44.

20. Khaodiar L, Ling PR, Blackburn GL, Bistrian BR. Serum levels of interleukin6 and c-reactive protein correlate with body mass index across the broad range of obesity. JPEN 2004;28(6):4105. 